\title{
Ecology of estuarine waters in small rivers of Southern Baikal in 2018
}

\author{
Zemskaya T.I. ${ }^{1}$, Bondarenko N.A. ${ }^{1}$, Bukin S.V. ${ }^{1}$, Bukin Y.S. ${ }^{1}$, Chernitsina S.M. ${ }^{1}$, \\ Ivanov V.G. ${ }^{1}$, Pimenov N.V. ${ }^{2}$, Pogodaeva T.V. ${ }^{1}$, Rusanov I.I. ${ }^{2}$, Shubenkova O.V. ${ }^{1}$, \\ Zakharenko A.S. ${ }^{1}$
}

${ }^{1}$ Limnological Institute, Siberian Branch of the Russian Academy of Sciences, Ulan-Batorskaya Str., 3, Irkutsk, 664033, Russia

${ }^{2}$ Winogradsky Institute of Microbiology, Research Center for Biotechnology, Russian Academy of Sciences, Moscow, 119071 Russia

\begin{abstract}
We conducted comprehensive studies in small rivers and estuarine water areas of Southern Baikal during the under-ice (March) and summer (July) periods of 2018. The chemical composition of water, the number of microorganisms, their diversity and metabolic potential in the studied areas correlated with the geographic location of the rivers, their flow and the degree of anthropogenic impact.
\end{abstract}

Keywords: Lake Baikal small tributaries, estuarine basins, chemical composition, ice and water microbial communities, dark $\mathrm{CO}_{2}$ assimilation, biodiversity

River ecosystems are used as sources of drinking water, for irrigation, industries and hydropower, and as transport and tourist routes; therefore, they are the most vulnerable aquatic ecosystems. Microorganisms that ensure the biochemical processes, as well as biodegradation and biotransformation of various pollutants, play a key role in the recovery and preservation of the state of these ecosystems (Kirchman, 1994; Bai et al., 2014; Ruiz-González et al., 2015; Wang et al., 2018). To date, much research has been done to assess the impact of domestic sewage on river ecosystems (Dugdale et al., 2013), which is also relevant for the tributaries of Lake Baikal (Drucker et al., 1993; Maksimov, 1995; Shtykova et al., 2016; Malnik et al., 2019). Small Baikal tributaries show an increase in the concentrations of phosphorus and nitrogen compounds as well as mass development of algae nonspecific for the littoral zone of Lake Baikal (Kravtsova et al., 2014; Khanaev et al., 2016; Timoshkin et al., 2016).

Using different approaches: cultivation, targeted sequencing of 16S rRNA genes, the metabolic activity of communities using radioactively labelled substrates, non-metric multidimensional scaling, and correlation analysis, we analysed chemical and microbiological data on the small rivers of Southern Baikal during the under-ice (March) and summer (July) periods of 2018.The obtained data demonstrate metabolic and taxonomic differences in bacterial communities between the river and estuarine water areas as well as in communities from southeastern and southwestern water areas of Lake Baikal.

Chemical parameters, total bacterial count
(TBC) and the number of various physiological groups of microorganisms in rivers and their estuarine water areas formed several clusters that correlated with the geographic location of the rivers, their flow and the degree of anthropogenic impact (Sinyukovich and Troitskaya, 2000; Zemskaya et al., 2019). As before, atmospheric precipitation enriched with the emissions of nitrogen oxide and sulphur from nearby thermal power stations affects the chemical composition of the rivers on both sides of Southern Baikal, which leads to the change in $\mathrm{pH}$ of water (Khodzher et al., 2002; Sorokovikova et al., 2002; Obolkin et al., 2016; Tomberg et al., 2016). The conducted studies have revealed that water in these rivers water does not undergo significant acidification that affects the vital activity of the bacterioplankton and phytoplankton communities (Bukin et al., 2020). Analysis of the data on the dark $\mathrm{CO}_{2}$ assimilation, TBC, the number of organotrophic, thermotolerant and faecal bacteria indicated the most polluted river and assessed the metabolic activity of communities depending on environmental conditions. During the under-ice period, the dark $\mathrm{CO}_{2}$ assimilation values were higher in the river and estuarine communities of microorganisms in the southeastern part of the lake compared to those in the southwestern part of Lake Baikal. In summer, we recorded higher values of this indicator: the rivers in the southwestern part of Southern Baikal, as well as the estuarine water areas in the southeastern part of Southern Baikal, showed the highest metabolic activity of microbial communities. The rivers and their estuarine water areas in the southwestern part of the lake are the

*Corresponding author.

E-mail address: tzema@lin.irk.ru (T.I. Zemskaya) 
most potentially hazardous for dinking purposes, where in different studied seasons, the number of coliform bacteria and spores of sulphate-reducing bacteria exceeded the ISO 9308-1, 2000 standards (Drucker et al., 1993; Maksimov, 1995; Shtykova et al., 2016; Malnik et al., 2019). The use of targeted sequencing of 16S rRNA genes for the analysis of communities of aquatic microorganisms allowed us to fully access the pollution sources, complementing the traditionally used indicators (for example, E. coli, enterococci) often used in monitoring programmes. As a positive point, we can indicate a decrease in the bacterial diversity in the estuarine areas, which can be due to the dilution of river waters with the Baikal waters, where we recorded less diverse composition of bacterial communities, as well as the death of allochthonous microflora exposed to other conditions.

Using the Illumina MiSeq platform, we studied the diversity of microorganisms in rivers, estuarine water areas and the pelagic zone during the under-ice and summer periods. In different seasons, the studied microbiomes showed the dominance of Cyanobacteria, Actinobacteria, Proteobacteria, Bacteroidetes, and Verrucomicrobia, which are widespread in other freshwater ecosystems (Newton et al., 2011). In the communities, we detected microorganisms involved in various stages of the transformation of organic and inorganic substances. The report will also discuss the difference in the taxonomic composition of microbiomes in the river and estuarine water areas.

\section{Acknowledgements}

The work was supported by the Collective Instrumental Center "Ultramicroanalysis" at the Limnological Institute Siberian Branch of the Russian Academy of Sciences, grant OFI-M no. 1729-05040, State Assignment 0345-2019-0007 (no. AAAA-A16-116122110064-7) of the Limnological Institute, and State Assignment of the Research Center for Biotechnology, Russian Academy of Sciences. This study was carried out using computational resources of the HPC-cluster «Akademik V.M. Matrosov» of Irkutsk Supercomputer Center of SB RAS and equipment of Core Centrum 'Genomic Technologies, Proteomics and Cell Biology' in ARRIAM.

\section{References}

Bai Y., Qi W., Liang J. et al. 2014. Using high-throughput sequencing to assess the impacts of treated and untreated wastewater discharge on prokaryotic communities in an urban river. Applied and Environmental Microbiology 98: 1841-1851. DOI: $10.1007 /$ s00253-013-5116-2

Bukin Y.S., Bondarenko N.A., Rusanov I.I. et al. 2020. Interconnection of bacterial and phytoplanktonic communities with hydrochemical parameters from ice and under-ice water in coastal zone of Lake Baikal. Scientific Reports 10. DOI: 10.1038/s41598-020-66519-3

Drucker V.V., Kostornova T.Ya., Molozhavaya O.A. et al. 1993. Quality assessment of Lake Baikal water according to sanitary and hygienic criteria. Geografiya i Prirodnyye Resursy [Geography and Natural Resources] 1: 60-64. (in Russian)
Dugdale R.C., Wilkerson F.P., Parker A.E. 2013. A biogeochemical model of phytoplankton productivity in an urban estuary: the importance of ammonium and freshwater flow. Ecological Modelling 263: 291-307. DOI: 10.1016/j. ecolmodel.2013.05.015

Khanaev I.V., Dzyuba E.V., Kravtsova L.S. et al. 2016. The effect of bloom of filamentous green algae on the reproduction of yellowfin sculpin Cottocomephorus grewingkii (Dybowski, 1874) (Cottoidae) during ecological crisis in Lake Baikal. Doklady Biological Sciences 467: 63-64. DOI: 10.1134/S0012496616020022

Khodzher T.V., Semenov M.Yu., Obolkin V.A. et al. 2002. Monitoring of acid deposition in the Baikal Region. Chemistry for Sustainable Development 10: 569-575.

Kirchman D.L. 1994. The uptake of inorganic nutrients by heterotrophic bacteria. Microbial Ecology 28: 255-271. DOI: $10.1007 / \mathrm{BF} 00166816$

Kravtsova L.S., Izhboldina L.A., Khanaev I.V. et al. 2014. Nearshore benthic blooms of filamentous green algae in Lake Baikal. Great Lakes Research 40: 441-448. DOI: 10.1016/j. jglr.2014.02.019

Maksimov V.V. 1995. Microbiology of large Baikal rivers and their estuarine water areas. Cand. Sc. Dissertation, Irkutsk State University, Irkutsk, Russia. (in Russian)

Malnik V.V., Timoshkin O.A., Suturin A.N. et al. 2019. Anthropogenic changes in the hydrochemical and sanitarymicrobiological characteristics of water quality in southern Baikal tributaries: Listvennichnyi Bay. Water Resources 46: 748-758. DOI: 10.1134/S0097807819050154

Newton R.J., Jones S.E., Eiler A. et al. 2011. A guide to the natural history of fresh water lake bacteria. Microbiology and Molecular Biology Reviews 75: 14-49. DOI: 10.1128/ MMBR.00028-10

Obolkin V., Khodzher T., Sorokovikova L. et al. 2016. Effect of long-range transport of sulphur and nitrogen oxides from large coal power plants on acidification of river waters in the Baikal region, East Siberia. International Journal of Environmental Studies 73: 452-461. DOI: 10.1080/00207233.2016.1165481

Ruiz-González C., Niño-García J.P., Giorgio P.A. 2015. Terrestrial origin of bacterial communitiesin complex boreal freshwater networks. Ecology Letters 18: 1198-1206. DOI: 10.1111/ele.12499

Shtykova Yu.R., Suslova M.Yu., Kostornova T.Ya. et al. 2016. Sanitary and microbiological monitoring in the Lake Baikal pelagic zone and Baikal's major tributaries from 2010 through 2015. Izvestiya Irkutskogo Gosudarstvennogo Universiteta. Seriya: Biologiya. Ekologiya [Irkutsk State University Bulletin. Series: Biology. Ecology] 17: 51-62. (in Russian)

Sinyukovich V.N., Troitskaya E.S. 2000. Average river runoff of the Baikal basin and its determination based on insufficient observation data. Geografiya i Prirodnyye Resursy [Geography and Natural Resources] 4: 60-64. (in Russian)

Sorokovikova L.M., Sinyukovaich V.N., Korovyakova I.V. et al. 2002. Formation of the chemical composition of the water of the Southern Baikal tributaries under modern conditions. Geografiya i Prirodnyye Resursy [Geography and Natural Resources] 4: 52-57. (in Russian)

Timoshkin O.A., Samsonov D.P., Yamamuro M. et al. 2016. Rapid ecological change in the coastal zone of Lake Baikal (East Siberia): is the site of the world's greatest freshwater biodiversity in danger? Journal of Great Lakes Research 42: 487-497. DOI: 10.1016/j.jglr.2016.02.011

Tomberg I.V., Sorokovikova L.M., Netsvetaeva O.G. et al. 2016. Chemical composition and trends of oxidation of snow waters and waters of South Baikal tributaries. Optika Atmosfery i Okeana [Atmospheric and Oceanic Optics] 29: 516-520. DOI: 10.15372/AOO20160612. (in Russian) 
Wang L., Zhang J., Li H. et al. 2018. Shift in the microbial community composition of surface water and sediment along an urban river. Science of the Total Environment 627: 600-612. DOI: 10.1016/j.scitotenv.2018.01.203

Zemskaya T.I., Bukin S.V., Zakharenko A.S. et al. 2019. Microbial communities in the estuarine water areas of the rivers in the southeastern part of Lake Baikal. Limnology and Freshwater Biology 4: 259-265. DOI:10.31951/2658-3518-2019-A-4-259 